\title{
Protective ventilation in ARDS: as soon as possible. An immediate use of HFOV
}

\author{
Philippe Ph Goutorbe*, Yves Y Asencio, Julien J Bordes, \\ Ambroise A Montcriol, Bertrand B Prunet and Eric E Meaudre
}

Address: Military teaching hospital Sainte Anne ICU department, Toulon, France

Email: Philippe Ph Goutorbe* - goutorbephil@live.fr; Yves Y Asencio - yves.asencio@free.fr; Julien J Bordes - bordes.julien@neuf.fr; Ambroise A Montcriol - ambroise.montcriol@free.fr; Bertrand B Prunet - prunet.bertrand@orange.fr; Eric E Meaudre - meaudre@club-internet.fr

* Corresponding author

Published: 22 August 2008

Cases Journal 2008, I:I24 doi:10.1 I86/I757-1626-I-124

This article is available from: http://www.casesjournal.com/content/I/I/I24

(C) 2008 Goutorbe et al; licensee BioMed Central Ltd.

This is an Open Access article distributed under the terms of the Creative Commons Attribution License (http://creativecommons.org/licenses/by/2.0), which permits unrestricted use, distribution, and reproduction in any medium, provided the original work is properly cited.

\section{Abstract}

Objective: To report the immediate use of High-Frequency Oscillatory ventilation in an adult acute respiratory distress syndrome.

Design: Case report.

Setting: Intensive care unit at the Military Teaching Hospital of Toulon.

Patient: A 64-yr-old Caucasian male who developed acute respiratory distress syndrome in the course of severe falciparum malaria.

Intervention: Initial use of HFO to minimise ventilator-induced lung injury.

Measurement and Main Results: Rapid improvement of $\mathrm{PaO} 2 /$ fraction of inspired oxygen from $172 \mathrm{mmHg}$ (NIV) to $310 \mathrm{mmHg}$ with HFO. No ventilator-induced injury on CT scan after 5 days of invasive ventilation.

Conclusion: In contrast with previous studies, we successfully used lung protective ventilation with HFO immediately. Further studies, with immediate, rather than rescue use of HFO ventilation, are needed.

\section{Introduction}

Although mechanical ventilation is often lifesaving for patients with acute respiratory distress syndrome (ARDS), it can itself cause further lung injury: ventilator induced lung injury (VILI)[1]. Three mechanisms lead to lung injury: gross air leaks (barotrauma), overdistension (volutrauma) and the cyclic opening and closing of unstable lung units (atelectrauma). This results in structural damage and biochemical injury with the systemic inflammatory response syndrome.
Lung-protective ventilation strategies have been developed to minimise VILI. Amato et al described in 1998 improved outcome in ARDS patients ventilated with small tidal volumes and positive end-expiratory pressures (PEEP) slightly above the lower inflection point on the pressure volume curve[2]. The ARDS net investigators reported in 2000 a $9 \%$ decrease in absolute mortality of patients with ARDS using small tidal volumes with a mean PEEP of $10 \mathrm{cmH} 2 \mathrm{O}[3]$. 
High-frequency oscillatory ventilation (HFOV) can provide adequate gas exchange with very small tidal volumes and thus achieve protective lung ventilation[4]. We report a case of malaria-related ARDS in which HFOV was used from the onset of ventilation. The early use of this protective ventilation may explain the absence of structural lung damage on the CT scan after 5 days.

\section{Case report}

The patient was a 64-yr-old caucasian with a history of fever following a stay in Ghana. He had not taken any anti-malarial chemoprophylaxis. On admission he was confused, thrombopenic (36000 giga per $\mathrm{ml}$ ), hyperbilirubinemic (77 micromoles/l) and in mild acute renal failure (urea 16.9; creatinine 130 micromoles/l). Blood examination showed a high concentration of plasmodium falciparum (parasitemia $=30 \%$ ).

Treatment included intravenous infusion of quinine and dalacine. On day 6 he presented with acute respiratory failure. The chest $X$ ray showed diffuse pulmonary oedema (fig 1). Echocardiography showed a normal ejection fraction and good diastolic function $(\mathrm{E} / \mathrm{Ea}=5)$ with a low brain natriuretic peptide ( 99 micromoles per $\mathrm{ml}$ ), which thus eliminated any cardiac cause for the edema. Fiber-optic guided distal protected lavage showed no bacterial culture. We concluded that the patient had an extrapulmonary acute respiratory distress syndrome triggered by malaria.

Non-invasive ventilation was tried for two hours without improvement in gas exchange $(\mathrm{PaO} 2 / \mathrm{FiO} 2=170 \mathrm{mmHg}$ with $\mathrm{FiO} 2$ of 0.5 ). The patient was intubated and HFOV started immediately, using a 3100B high-frequency oscillatory ventilator (SensorMedics, Yorba Linda, CA).

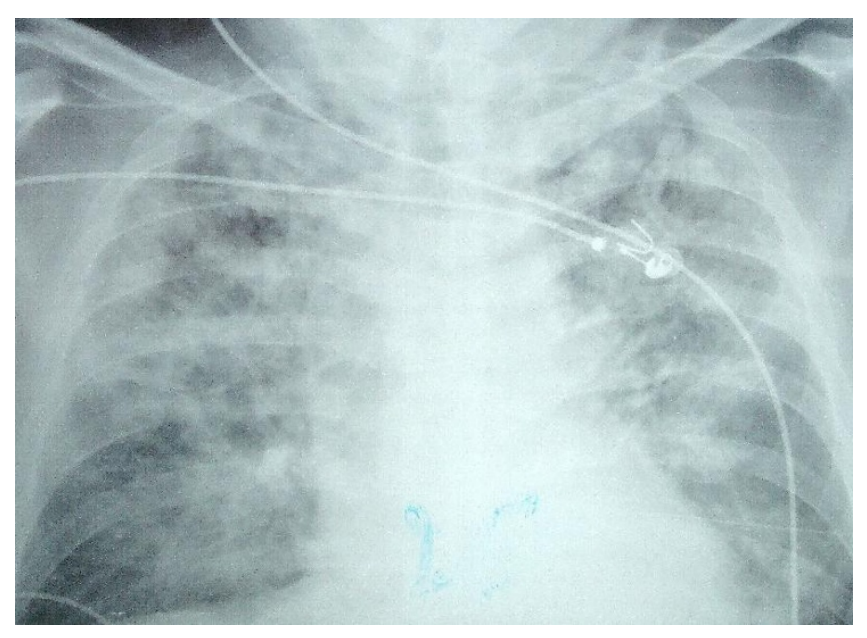

Figure I

Chest $X$ ray just before intubation.
Initial HFO settings was:

Bias flow $40 \mathrm{~L} / \mathrm{min}$.

$\mathrm{FiO} 20,7$.

Inspiratory time $=32 \%$.

$\mathrm{MPaw}=27 \mathrm{cmH}_{2} \mathrm{O}$.

Amplitude $(\Delta \mathrm{P})=90 \mathrm{cmH}_{2} \mathrm{O}$.

Frequency $=4,5 \mathrm{~Hz}$.

Gas exchange improved rapidly. After four hours, $\mathrm{PaO} 2 /$ $\mathrm{FiO} 2$ was $310 \mathrm{mmHg}$ with an $\mathrm{FiO} 2$ of 0,7 . $\mathrm{FiO} 2$ was reduced to 0,4 and Mpaw to $22 \mathrm{cmH}_{2} \mathrm{O}$. After 48 hours we returned to conventional ventilation.

After 5 days of invasive ventilation a CT scan, performed during an inspiratory pause of $15 \mathrm{cmH}_{2} \mathrm{O}$, showed a structurally normal lung, without any ventilator induced lung injury (Fig 2). The patient was successfully extubated after 11 days of invasive ventilation, and was discharged from ICU on day 19. He returned home on day 25 without any sequellae.

\section{Discussion}

Adequate ventilation is an important endpoint in the management of in ARDS. Several protective ventilation strategies have been described, of which small tidal volume with a mean PEEP of $10 \mathrm{cmH}_{2} \mathrm{O}$ is the most common[3]. Extra corporeal gas exchange is also used with very small tidal volumes and low frequency. HFOV provides alveolar ventilation with very small tidal volumes and thus theoretically provide an optimal lung-protective ventilatory strategy[5].

Gas exchange during HFOV depends on different mechanisms: interregional gas mixing between units with different time constants (Pendelluft), convective transport attributable to asymmetry between inspiratory and expiratory profiles, cardiac oscillation, collateral ventilation and Taylor dispersion. These mechanisms allow adequate oxygenation and $\mathrm{CO} 2$ clearance with tidal volumes of only $1-3 \mathrm{ml} / \mathrm{Kg}[6,7]$. In addition, the raised mean airway pressure can achieve lung recruitment despite unequal time constants, and prevents end-expiratory alveolar collapse[8].

Treggiari $\mathrm{M}$ et al described two types of structural lung damage related to ventilation; air cyst and bronchiectasis[9]. There was a positive correlation between the duration of mechanical ventilation and the amount of lung damage. Moreover a negative correlation was noted 

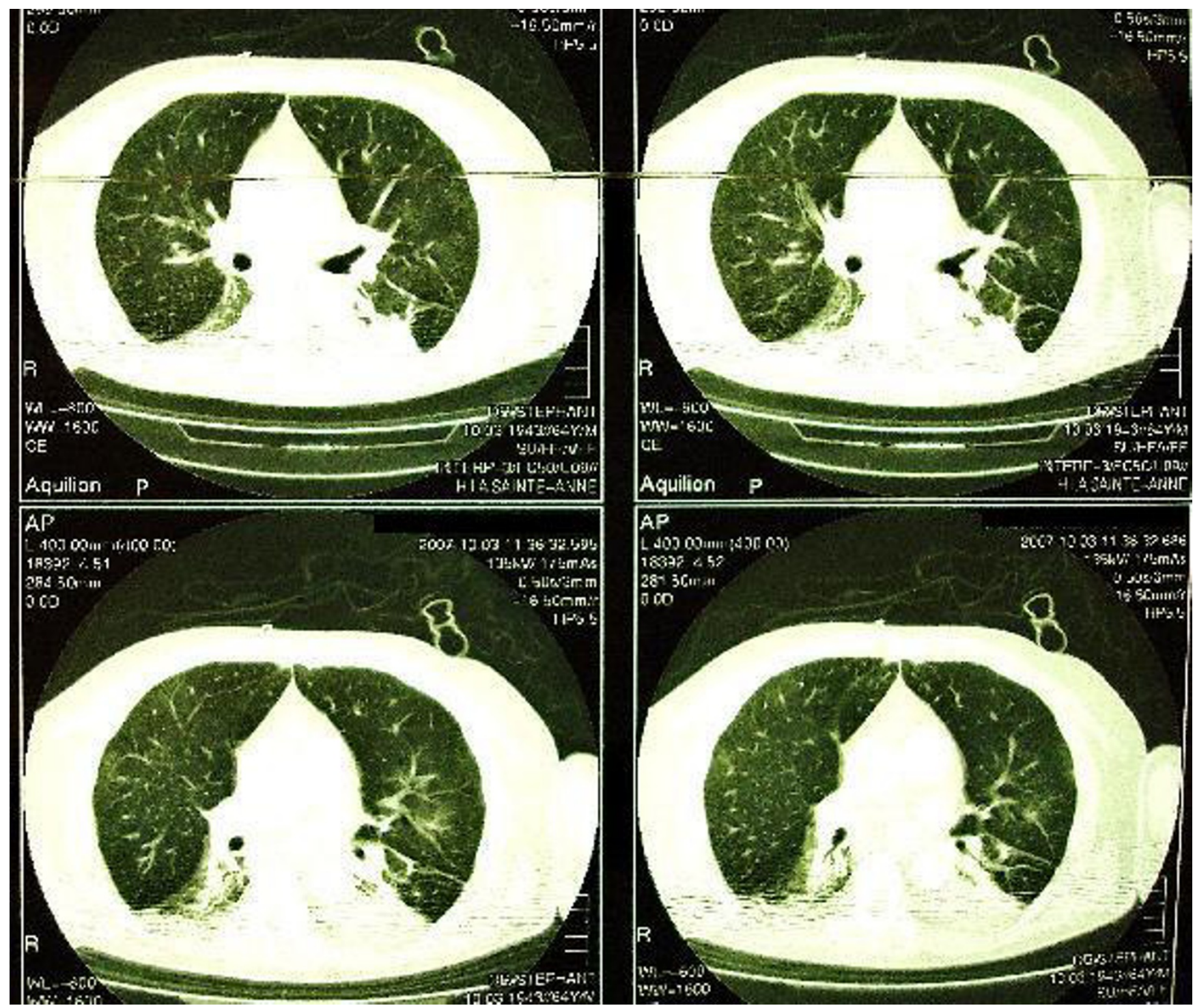

\section{Figure 2}

CT Scan on day 5.

between the volume of normal parenchyma and the mean end-inspiratory pressure. In our patient the normal CT scan on day 5 was attributed to the immediate protective effects of HFOV.

The immediate use of a lung-protective strategy is justified on theoretical grounds. However, the time at which HFOV should be initiated is controversial[10]. Four trials, of which three were prospective, identified the duration of prior conventional ventilation as an independent predictor of mortality in ARDS. A systematic review of nine studies found that the duration of conventional ventilation prior to starting HFOV was significantly greater in nonsurvivors. When adjusted for age and APACHE II score, each extra day on conventional ventilation was associated with a $20 \%$ increase in mortality, although this association disappeared when baseline $\mathrm{pH}$ was included in the multivariate analysis (enable data for five study)[11].

We think that HFOV is a highly lung-protective strategy which should be used in ARDS as soon as possible, especially in early and diffuse ARDS. Further trials with immediate use of HFOV are required to confirm this.

\section{Abbreviations}

ARDS: Acute respiratory distress syndrome; HFOV: Highfrequency oscillatory ventilation; Mpaw: Mean airway 
pressure; PEEP: Positive end-expiratory pressures; VILI: Ventilator induced lung injury.

\section{Competing interests}

The authors declare that they have no competing interests.

\section{Authors' contributions}

All the authors contribute to the treatment of this patient.

\section{Consent}

Written informed consent was obtained from the patient for publication of this case report and accompanying images. A copy of the written consent is available for review by the Editor-in-Chief of this journal.

\section{References}

I. Dreyfuss D, Saumon G: Ventilator-induced lung injury: lessons from experimental studies. Am J Respir Crit Care Med 1998, I 57:294-323.

2. Amato MB, Barbas CS, Medeiros DM, et al.: Beneficial effects of the "open lung approach" with low distending pressures in acute respiratory distress syndrome. A prospective randomized study on mechanical ventilation. Am J Respir Crit Care Med 1995, 152: 1835-46.

3. Ventilation with lower tidal volumes as compared with traditional tidal volumes for acute lung injury and the acute respiratory distress syndrome. The Acute Respiratory Distress Syndrome Network. N Engl] Med 2000, 342:130I-8.

4. Imai $Y$, Slutsky AS: High-frequency oscillatory ventilation and ventilator-induced lung injury. Crit Care Med 2005, 33:SI29-34.

5. Downar J, Mehta S: Bench-to-bedside review: high-frequency oscillatory ventilation in adults with acute respiratory distress syndrome. Crit Care 2006, 10:240.

6. Kacmarek RM, Malhotra A: High-frequency oscillatory ventilation: what large-animal studies have taught us! Crit Care Med 2005, 33:SI48-54.

7. Schmid ER, Knopp TJ, Rehder K: Intrapulmonary gas transport and perfusion during high-frequency oscillation. J Appl Physiol |98I, 5 I:I507-|4.

8. Kacmarek RM: Ventilatory management of ARDS: high frequency oscillation and lung recruitment! Crit Care 2006, 10:158.

9. Treggiari MM, Romand JA, Martin JB, Suter PM: Air cysts and bronchiectasis prevail in nondependent areas in severe acute respiratory distress syndrome: a computed tomographic study of ventilator-associated changes. Crit Care Med 2002, 30:1747-52.

10. Bryan AC: The oscillations of HFO. Am J Respir Crit Care Med 200I, 163:8I6-7.

II. Bollen CW, Uiterwaal CS, van Vught A): Systematic review of determinants of mortality in high frequency oscillatory ventilation in acute respiratory distress syndrome. Crit Care 2006, I0:R34.
Publish with Bio Med Central and every scientist can read your work free of charge

"BioMed Central will be the most significant development for disseminating the results of biomedical research in our lifetime. "

Sir Paul Nurse, Cancer Research UK

Your research papers will be:

- available free of charge to the entire biomedical community

- peer reviewed and published immediately upon acceptance

- cited in PubMed and archived on PubMed Central

- yours - you keep the copyright
BioMedcentral 